This article was downloaded by: [Carnegie Mellon University]

On: 20 January 2015, At: 01:40

Publisher: Routledge

Informa Ltd Registered in England and Wales Registered Number: 1072954 Registered office: Mortimer House, 37-41 Mortimer Street, London W1T 3J H, UK

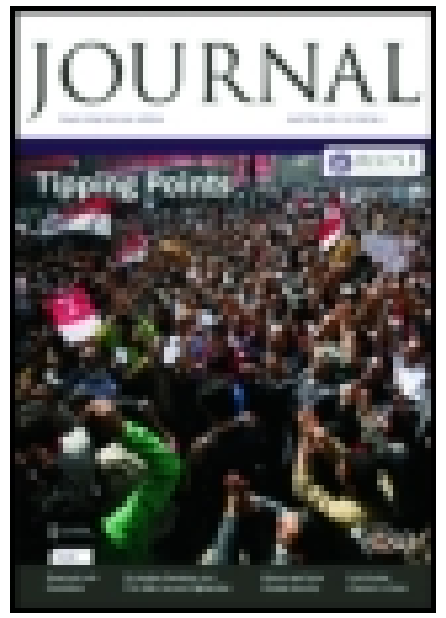

Royal United Services Institution. J ournal

Publication details, including instructions for authors and subscription information: http:// www. tandfonline.com/ loi/rusi 19

\title{
Non-Commissioned Officers in Continental Armies
}

J ohn Ross

Published online: 11 Sep 2009.

To cite this article: J ohn Ross (1878) Non-Commissioned Officers in Continental Armies, Royal United Services Institution. J ournal, 22:94, 221-260, DOI: 10.1080/03071847809416345

To link to this article: http://

dx. doi.org/ 10.1080/03071847809416345

\section{PLEASE SCROLL DOWN FOR ARTICLE}

Taylor \& Francis makes every effort to ensure the accuracy of all the information (the "Content") contained in the publications on our platform. However, Taylor \& Francis, our agents, and our licensors make no representations or warranties whatsoever as to the accuracy, completeness, or suitability for any purpose of the Content. Any opinions 
and views expressed in this publication are the opinions and views of the authors, and are not the views of or endorsed by Taylor \& Francis. The accuracy of the Content should not be relied upon and should be independently verified with primary sources of information. Taylor and Francis shall not be liable for any losses, actions, claims, proceedings, demands, costs, expenses, damages, and other liabilities whatsoever or howsoever caused arising directly or indirectly in connection with, in relation to or arising out of the use of the Content.

This article may be used for research, teaching, and private study purposes. Any substantial or systematic reproduction, redistribution, reselling, loan, sub-licensing, systematic supply, or distribution in any form to anyone is expressly forbidden. Terms \& Conditions of access and use can be found at http://www.tandfonline.com/page/terms-andconditions 


\title{
NON-CONGMISSIONED OFFICERS IN CONTINI ARIIIES.
}

\author{
By JoHx Ross of Bladensberg, Coldstream Grar
}

THE question of obtaining a good class of non-commissii is one which is occupying the serious attention of most nations. Men for service in the ranks are obtained easily so as a rule are Officers, but the grade connecting the twi Gorernments can indeed afford to be very careful in 50 Officers; and considering low much of the success in r upon them, too much attention can hardly be given to those on whom commissions are bestowed are in every $\mathrm{w}$ their position. Ambition, the desire to embrace a manl: of enterprise and popular in societ 5 , make many wis ${ }^{3}$ Officers, bat not so non-commissioned officers. Their littlo attached to it to make it attractive; it is subordi honourable discharge of its duties is rewarded, rather by of satisfaction than by any more substantial recompen long service, perhaps spent in night work, in bad clim campaigns, a nan often finds himself imporerished, brok and unable to take his place among those neighbours themselres to walks in ciril life.

The presenco of a gcod subordinate class of officials for all armies, bat it is so now more than ever. Modem armies are not what thes used to be; now they are regu an extended and national war organization, through batches of recruits have to pass, and where a continu; and drill converts the peasant into a soldier. Tactics aIse in the last few years have imposed new responsibilities 1 commissioned officer; there is a greater necessity for ind and intelligence than formerly, and in the late Franco: there were even cases in which sergeants were tempore at critical moments-with small commands owing to the Officers. To falfil these new duties, the good old type abroad in the Prussian corporal of Frederick the Great and is dying out rapidly; and there is a great difficul in inducing the middie classes of society to embrace a rr or, at all erents, to derote some time beyond the obligato service of the country. The increase of manufacturis commercial enterprise is the principal cause which ke class, which would be so useful as non-commissioned Q 2 
can get high wages and live in affluent circumstances in . should they then put up with the chequered life of a sols Rhenish and Westphalian provinces it was found mor retain the services of men quartered there, than in the Eas of the German Empire, and for the same reason; high r be found in the former, bat not so readily in the latter. universal servico now adopted abroad has also, in a $\mathrm{g}$ : increased the difficulty. That plan gives powerful arn reserves; soldiers exclusively so by profession are disca whole male population is trained to arms, and every ma tax in personal service before he is permitted to derote $b$ profession or occupation in life. The short training is mould the masses into soldiers, but not so to form good sioned officers; also they are too young and inexperienc is quite enough to do in the regiments, to attend to the $r$ constantly arrive. In former days when long service , those who entered the Army knew that a large portion would be spent under the colours; the smartest of naturally seek to gain the top of their profession, and highest pay and best pensions. But not so in compulso: short periods; there they will get it over as soon as possib ing themselves in their ciril pursuits, try and forget all a life.

If the Government could enlarge its expenses and cc labour market, there can be no doubt that it could obtais of the best men of the country for non-commissioned a it must be remembered that every nation is oppressed already well nigh insupportable, owing to its bloated arm: could spend anything more, and thus each seeks to solve by other means than that of inflicting an additional and upon the people; economy, very rigid economy, is the which they can act.

One of the chief means of obtaining the necessary qt for non-commissioned officers in modern armies, is the special schools or corps of instrnction. Germany and Itc seen, have adopted this plan very largely. The bes naturally in which to train joung men who hope for $\mathrm{pr}$ the ranks. It is there that they learn to appreciate the $f_{1}$ men, and are tanght to respect the traditions of their ic customs of the service; it is there that their characters a their superiors, and the degree of advancement they are tained; and it is there they gain instruction, experier. which are all so absolutely necessary. But as there is : this, in modern armies-if the men will not re.engag obligatory service-a more rapid mode of training has by these schools. There are, however, some drawbacks $t$ the men who issue from instruction as sergeants ar younger often and perhaps inferior in attainments to $\mathrm{m}$ whom they are placed over. They will always form a to the rest of the Army, and hare little in common with 
file, of whose prejudices they must necessarily be ignoran will, it is true, be a learen of older and re-engaged sergeants give their tone to their juniors, and prevent them from ab power which they have got so easily; but this will not comp the disadrantages of the system. It must be remembered schools for training non-commissioned officers ais very cos State, and especially so when, as in Germany, it is found net establish a preparatory school. Thus the country pays for $t$ tion of men who are to fill quite subordinate post3, during $w$ they are maintained at the public expense, althongh they $p$ military service.

The best means of securing good non-commissioned offi induce them to re-engage. This is mainly done by giving $t$ pay during their re-engaged service, and a bounty or pens: end of a certain time, together with the prospect of a situat civil service of the country. It has been found that to ensu fortable future to a man is the best menns of inducing him on after his first torm of service; and a question arises of portance, whether it is advisable to do this by granting plac ways, telegraphs, post, and other offices. Old soldiers with discipline, order, and regularity, are very likely to discharge duties very well, but it is erident if they are the only clc community who are to get these posts, a very important pe national wealth is unduly burdened. Although they maj educated they may not suit the place, and if they get it rather than merit, they have not the same reason to try a their employers. The numerous decrees also issued to sec tions for old soldiers, lead to the belief, indeed, that if an c petition were to be allowed, and the best men only chosen. commissioned officers would not by any means always get tl the other hand, the inducement held out by the hope of civi ment is not considered sufficient to keep men in the ranks a obligatory service. According to reports from France, $t$ number of old non-commissioned officers proposed for civil pos to prove conclusively the mistake in thinking that this met will keep them under the colours. There are also some in 1 where as will be seen this system is most relied upon, who that it is unwise, and unduly taxes the civil administratic country, and they believe that a sum of money should be give

But how is this money to be raised? In Italy a special $f$ apart for the payment of these bounties, and the principle appears to have great adrantages. It is based on this :-mil: is obligatory to all, but some do not serre, either they can weakness or other causes, or they enter the ranks as one-ye teers; these then are taxed, and can be made to pay a fin The money so acquired is devoted to the non-commissione fund. In Italy, it will be seen, the fines paid by one-year T are applicable to this purpose; also in Austria money is as will appear, from the intorest derived from funds, obtai those who did not serre the State in personal serrice; but 
else is the principle eren in force at present. In Frar posals to that effect hare been made, bat the desire to year volunteers and the fear that exemptions may agai by mone5, will probably prevent them from being eres Some such system was in force in Bavaria for a short ti: late war; old non-commissioned officers received a bc gulden (£66 13s. 4d.), which was paid out of a func the fincs (called vehrgeld) of those incapable of serrin:

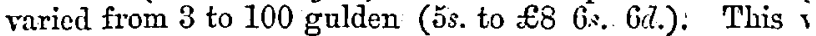
in 1871, the Germans considering that in some way it the thin edge of the wedge, and end in monetary payn stitutes:

There are a number of men who, from physical infirm causes, are unable to serve at all; there are also those, $v$ liable and able to serve, get off on account of the con strong enough without them; and it: would seem. but $f$ should pay in purse that which they cannot pay in $p_{1}$ men, of course, are afflicted by nature to such an extent; burdens ou their families; but there are others who, from ness or eren tardy growth, cannot bear the fatigue of a but who can easily earn a lirelihood. The former sho not be taxed; but the latter by paying no fine, get off at free, and benefit immensely by their contemporaries being because they have the field to themselres and get a thri of them. These should be made to pay the wehrgeld. objected that for the country to pay annually a sum of is not levied at the time by Parliamentary rote, is a prin foreign to our ideas; doubtless it is so, and so ought it all constitutional nations. But, is not nniversal ane serrice; the very cssence of a tax raised without the sar liament? If most have to pay their dues to the State giving up the fruit of their labour and the ralne of th should the remainder come off scot free, and shield the loss behind a constitutional principle already broken? as we have said, other reasons haro abolished the wehrg might be got over; of course, care should be taken I able-bodied men to get off their term of scrvice by paym and a system of checks could be arranged for this purpo of substitutes for military duty for a sum of money is foreign to the Prussian organization; one-year volur another form of it. 'This institution is doubtless a nece its presence shows that the military laws of eren Ger bend to circumstances; and it may be; that a judicious the wchrgeld system could form a fund which is so imp. reward of non-commissioned officers, who hare serv number of years in the Army. If the wehrgeld we throughout the German Empire, it would be the mea - lated, of procuring three to four millicn thalers ( $\$ 450,00$ r annually, and this would be ample to supply all necessitj The Bulletin de la Réunion des' Officiers has published : 
remarks from the Allgemcine Militaive Zeitung, advocating : tax in the German Empire, for the benefit of the non-com officers. This is a species of poll-tax to be raised on all $T$ reaching the age of twenty. The following is the calculatio it were imposed:-at twenty marks (£1) per head, and wit: contributors, a yearly sum of about 10;500,000 marks are The German Army has about 48,000 non-commissioned office a third of this number re-engage and receive 300 marks $F$ as extra pay, a little less than 5,000,000 marks are spent. mainder is then in hand for the relief of those widows or orf have lost their relations in war time:

An important part of the question under consideration to be examined-promotion from the ranks. France has adopted this system, being probably impelled thereto by her 1 notions. The corps of Officers in that country is recruited, students at military colleges, and, secondly, from uon-con officers. The latter formed about one-third of the whole, attained the lowest grade in their new sphere before the age As a rule they were good and efficient non-commissioned 0 thoroughly unfit in education or in general attainments to fo body of Officers, for without early training they could $n$ efficient commanders. These promotions then split up th Officers into two distinct classes, and destroyed that union ar which is so essential. Added to this, however; those who * the ranks, being unfit for promotion to the higher gradessergeants would make efficient Generals or even Colonels-7 over by their founger and more intelligent companions military colleges, and all the best positions in the Army we these latter. The others then found themselves neglected, seded by juniors, who, apparently, were on the same footin selres. Nor was this all, for so great an influx of men be the lower and middle classes of society,; into the body' ' militated against the social position of the whole corps; commissions unpopular to those who from birth, antece education would make the best, the most intelligent, and $\mathrm{mr}$ leaders of the Army. Such was the organization which k so signally in 1870, and such it remains still, vith the that the self-sacrificing efforts of every one in Frauce will remedy any defect in this ssstem. An attempt has now be educate those non-commissioned officers destiued for prom this plan has been adopted in Italy, where no sergeant car to the "epaulettes," without going through the school set the purpose; this is also the case for the infantry. in Fran adopt this plan; in order to obtain a revard for non-co: officers, is a mistake, it being open to precisely the same already related. Again, men who have passed years in position will often regard their elevation not so much as point to future work and advancement, but as the end of tion; their new duties will then be discharged rather with $\mathrm{i}$ than with zeal. In fact, promotion from the ranks sa 
welfare of the corps of Officers, in the hope of benefiting non-commissioned officers-a system which is altogether $\mathrm{s}$.

On examination, however, it will be found that neitl plan benefit that class which it is meant to reward. Thein not fixed but transitory and instable. The general desirc commission, and those that fail in their object-all cann have missed their vocation in life, and are consequently and weary of their profession; there will then be a lar disappointed non-commissioned officers, certainly no adva service. Some in France consider that either too many commissions are giren; it is not the prize of the special nor the lot of all sergeants; they compare this state of that in the French Navy, where promotion from the ranks Petty officers of the fleet are said to be far better men ar tented than their equals in the sister service; they have of position in life, in which an honourable career is to be fou do not crave after an ambition which most cannot reach which discourages and incapacitates them from further fact, "l'homme préfére être le premier dans une licoque $q$ ? "Rome."

At best, a commission is but a doubtful reward to a : up to a different state of society, and the Germans, with $n$ have instituted quite a different state of things. The moting non-commissioned officers for the sake of indu class of men to serve as such, is considered entirely. corps of Officers must not be injured; its rôle is all-im. to carry it out wo must hare a carefully-trained and class of men, able to direct with judgment and to lead It is, of course, understood that there can be no objerti an advantage, when men show themselres competent to selres from a subordinate position to one of trust and door can never bo irrevocably shut which separates one Army from another. Bat men should never be so elevate are worthy of it; and to be worthy of it, more, far more than the mere humdrum of respectable service. The Officer should be a high privilege and a position demand exalted characteristics; this rank cannot be within the proportion of those that enlist; and to affirm that it i allow a commission to be the reward of every respectable clever non-commissioned officer, is the same thing as to s: solicitor's clerk, who can copy legibly and behave dec obtain the highest position in the legal profession. Life of different orders, and each have their duties; a man may perhaps be eminently fitted to another above him, $b r$ another thing to ignore these ordors in the world, and to they do not exist; it degrades the highest honours of a brings no satisfaction to the men themselves thus unduly In turning now to the regulations in force in some of Powers of Europe, it will be seen how each has en। procure good non-commissioned officers for its Army. 
England the supply of these has not yet become a serio But taking into consideration the troubles of other nati as the commercial peculiarities of this country, it is high that if erer we should attempt to convert onr people $f$ s armed masses, a great difficulty would be the question of cure non-commissioned officers.

\section{Germany. \\ Non-commissioned officers in Germany are obtained sources:}

1. From gefreite (answering to our lance corporals) ar men of good character, who know their duty, who can read reckon, and who have re-engnged (capitulaten). These, be practically trained, are taught in the regimental schools winter months, three to five times a-week, arithmet; grammar, elementary geography, and history. An Offic over this instruction; the students also do not get off any undergoing the course. In the artillery the non-commissic are principally drawn from this class, and especially from volunteers. Candidates, after a year's service, and afte written examination, are appointed obergefreite (bombardier battery are afterwards sent to the school of the regiment $t_{1}$ course of instruction, 'which lasts from 1st October to April, and which includes artillery, mathematics, interio writing, and veterinary science. On terminating this cou torily, the oliergefreite receires a certificate, which qualifies grade of corporal, and after another year's service, a written examination, he is appointed as such, as a race To rise higher, he must undergo a stiffer examination.

2. From men of good conduct who have not yet com: obligatory term in the ranks, and who do not wish to re-en? .pulsory service in Germany is very short; nominally thi often scarcely exceeds two years and a-half, and in the smartest men who obtain the King's leare (Köenigs Urlau hare passed their drills satisfactorily, it is not more than The number of these latter is about twenty per company a is consequently not easy for the military authorities to non-commissoned officers with the yearly contingent, an where privates are promoted, who do not re-engage, are only resorted to where men are likely to be of use, an others are arailable, which is sometimes the case in som quartered in uncomfortable places. Ont of 29,159 r sioned officers of the German Army in 1875, 2,414 belor class.

3. From non-commissioned officers' schools.

Germany was the first to found schools for the educal commissioned officers. They grew out of an institution from philanthropic motives in Potsdam in 1824, for the bringing up orphans of soldiers to a military career. Afte at the school, the bojs were sent to the Instractional be 
attached as a special dirision; and threo years later they arm5, with the rank of corporal. The General in comm Guard Corps had superior control over this school, and $t$ tanght therein were mado to embrace everything necessar, good non-commissioned officer; in fact, the boss were servo in that capacity; all attempts made to elerato the into a Cadet College for Officers were checked, and finally p] a Cabinet Order dated March, 1839. This school having of public adrantago was increased; in 1831 it was double it became three companics strong, and in 1858, four co: one battalion. In 1860 a new school was erected at Jul from that of Potsdam; and in 1864, additions were made of each. In 1867 a third school was founded at Biebrich later a fourth at Weissenfels; again, in 1871, the Imper was giren to a fifth at Ettlingen, which had already exi Baden Army; and lastly; in 1873, a sixth was established werder in Saxony. These have, therefore, now beco national institution, and in 1872 an Officer, with the ran] General, was appointed to inspect and control them. TH under the command of a Field Officer, or a Captain of standj mandant; and they muster some 500 students each, togethes of Officers and non-commissioned officers. In order to in class of the latter, to instil proper ideas of military discip.' minds of the students, adrantages are given to them in ex increased chances of promotion.

Candidates for admission must bo over 17 (14-in $S$ : under 20; they must hare a certificate of good characte1 simple examination in reading, writing, and arithmetic ( first four elementary rules). On admittance, they must an agreement, by which they engage to remain in the $S$ legal time ( 3 jears); and besides a term of jears, equal $t$ period they spend in the school. This period varies $f$ three years; according to the capability of the pupil, an military serrice. Thus the State ensures that each man will remain efficient in the ranks as a non-commissione fire or sir years; latterly, it appears it has been reduced t The instruction giren is practical rather than theoretical, making the aspirant able to teach all that is necessary, set an example of military smartness-writing, reading elementary history and geography, German, writing SI reports, sketching, and singing, are also taught. Goo receire four weeks' holidays per year, their journoys hor being paid for them:

When fit to pass ont of these schools the students are $p$ regiments, their distribution being so arranged that tho: have sent non-commissioned officers to the staff of the receire, if possible, three from the school in place of ea as instructors; otherwise the ordinary racancies are flled of any one for a particular regiment being taken into as much as possible; thirty of the best go annually to tl 
specially recommended they are made corporals six mor leaving the school; at the cad of their term of instruction the ranks all reccire the bounty given to re-engaged men.

Last year another step has been taken in the educati commissioned officers of the German ArmJ. It lias been the schools lave not altogether sacceeded; the Governmen for individual reports on each man obtained from them, an appears to be that while they are considerced satisfactory. attainments, their moral characters are very bad. In fa that the class of men required has not yet been got hold for-nothing lads; whose parents are glad to get rid of th themselres in plenty; and thus, while the schools are $f$ characters, the right stamp of mon do not apply for. It is rery probable that this has prerented a greater derc these schools from being carried out. Another attempt $j$ being made to rectify these defects. It is found that classes place their sons in business at about 15 , and that rial is thus lost (the earliest age of admittance in the non-cc officers' schools being 17). A preparatory non.commissios school has therefore just: been opened at Weilburg for tht feeding the others, and the class of boss to be so obtain with the really good stuff already procured - sons of old n sioned officers-will, it is hoped, produce the elements req Army.

Candidates for this preparatory school must be over under sixteen; they must have an irreproachable cond health, know how to write legibly, read print, and underst. four clementary rules of arithmetic. They must preșer consent of their father or gnardian to tho step they are 1 must engage in writing to enter the non-commissioned of on completion of the preparators course, by which they af in the ranks four jears, i.e., two years for every one in the school. The boys are not soldiers nor undèr the militar they enter the non-commissioned officers' school, but th get out of their engagement by paying their expenses, $w$ to 465 marks (about $£ 23$ ) per year. The course lasts tv Government pays for everything, feeding, clothing, $]_{1}$ edncation; anything of a teclnically military nature is but all which tends to invigorate the body, gymuntics, fe: ming, \&c., is specially attended to. Pupils from this sc another two years at the higher school, or less if they. physically and in education; they then enter tho ranks as

There were many applications for admittance into thi at Weilburg, and many had to be refused, and it is proba ceeds that others like it will be established; this year fror boys are admitted, next year it is lioped that the full co 250 can be lodged:

These arrangements only secure the serrices of a ma time (four years) with the colours, which is not onough; 1 would be too young and inexperienced, and little likely $t c$ 
benefit to the service. An old and steady element is ther lutely required. The Germans, as all other nations, have co set a high value upon re-engagements, and have tried to $\mathrm{i}$ to romain on in the service. Theso re-ongagements are $\mathrm{m}$ jear at a time, with the consent of the Captain of the squadron, or battery. By this means a man can leave if he w so, without being tied to serre for a number of years, while, conduct not be considered satisfactory, the Commanding $C$ get rid of him casily. The fear of this will keep a man wl re-engaged attentive to his duties, because unless he serve number of years, he will not have a right to the advantages regulations hold out, and which induced him to embrace carcer. These rewards are principally giren by appointme posts, rather than by pensions or bounties; in fact, the Ge1 to make the rank of a non-commissioned officer the necessar. stone to employment in the different civil appointments of $t$

As far back as 1867 it was decreed that non-commission after twelve jears' service, might obtain civil posts (if $f$ the following order: (1) those invalided, preference bein those who are wounded or decorated, (2) those "half-iny fit for garrison duty only, and (3) those who hare ret: health and strength. As long as there are military can these situations, civilians were to be debarred from compet:

In 1873 new advantages were conferred on non-cor officers :-

(1.) Their pay was increased, in some instances 30 and , cent.

(2.) Two new ranks woro created, that of vice-felducebel, sergeant-major, one per company, and usually given to an c as a reward after fifteen years' service. It has no responsil the pay is 3 thalers $(9 s$.) a month bigher than that of serg other is a new pay-clerk per battalion, a post of trust whic man to rise to Paymaster (Zahlmeister).

(3.) Their allowances and barrack comforts were incr geants' messes started, and certain other privileges and cou were extended to them, amongst others the obligation on the soldier to address them by the title Herr (Sir).

Next year other regulations were issued (April, 1874) pensions were conferred; which were divided into five clas

\begin{tabular}{|c|c|c|c|c|c|c|c|c|}
\hline \multicolumn{2}{|c|}{ 1st class per month } & \multicolumn{4}{|c|}{ Sergeant-major. } & \multicolumn{2}{|c|}{ Sergeant. } & \\
\hline 2nd & $"$ & $\ldots$ & 11 & $"$ & .. & 9 & $"$ & \\
\hline$"$ & $"$ & .... & 9 & $"$ & .. & 7 & ” & $\cdots$ \\
\hline$"$ & " & $\ldots$ & 7 & ", & .. & 5 & " & . \\
\hline ", & ", & ... & 5 & $"$ & .. & 4 & ", & \\
\hline
\end{tabular}

Non-commissioned officers are entitled (if not invalided) to pension after 36 jears' service, 2nd class after 30 years' class after 24 years' service, and 4th class after 18 years' $\mathrm{s}$ abore are not paid if the pensioner ceases to be a Germar 
if he receives a civil post worth a certain sum. It is con: a sergeant-major should at least have a salary of 350 th: £52), and a sergeant or corporal 250 thalers (about £37) : if the situation does not amount to this, the difference is him, out of the pension be would have got, had he not $h$ Moreorer, pensions are given according to the rank held the man has possessed it for twelve jears; otherwise (unle: for wounds, \&c., received in the country's service) accor rank immediately inforior to it.

Invalid non-commissioned officers are dirided into those $f$ so from natural causes, and those that are injured on serv former, the following are the pensions to be obtained :-

(1.) A Ist class pension after 25 years' service, if uni without the assistance of strangers.

(2.) A 2nd class pension after 20 years' sarvice, if una a livelihood.

(3.) A 3rd class pension nfter 15 years' service, if near] of earning. a livelihood.

(4.) A 4th class pension after 12 years' service, if partiall of earning a livelihood.

(5.) And a 5 th class pension after 8 years' service, if ak livelihood.

If the latter, then the following :-

(1.) A 1st class pension is given for any service, long the man is unable to live without the assistance of stranger

(2.) A 2nd class pension when incapable of earning a liv

(3.) A 3rd class pension when nearly incapable.

(4.) A 4th class pension when partially incapable.

(5.) A 5th class pension when able to gain a living.

In all these cases certificates to obtain civil posts are gi the man bo of a sufficiently good character, and in many $c$ certain additions are made for good service.

These additions are given :-

(1.) If entirely invalided.iı war, 2 thalers per month.

(2.) For each mutilation, loss of a limb, or other ser 6 thalers per month. The total not to exceed 12 thalers ( is, however, considered as extra, 6 thalers for cach eye blin

(3.) Then completely invalided after 18 years' service.

(4.) To those unable to make any use of their certificat employments in civil life, owing to injuries received in 3 thalers monthly, in lien of such certificate.

It may be remarked that the Germans also give facilities to marry, provided they place 100 thalers in the Savings $B$ corps, for which they obtain interest. Quarters are gire] possible to do so, and a certain sum of money is pat by, for tl of their sons. Also a pension to the widow and orphans of in war, or who die afterwards from their wounds.

The employments offered to non-commissioned officers of $t$ qualifications, were at first confined to the State railways, post offices, and evergthing uuder the Government; but $t$ 
ment does not seem to have answered its purpose sufficiently to offer a substantial inducement to men to remain their twel the Army. It is calculated that there were some $34,000 \mathrm{p}$ ] to soldiers, but that they were not all filled; the pay attaclie of them was a small and insufficient reward, and thus it was: the number of re-engagements diminished every year. TH tions of 1874 had the effect of only slightly increasing the those who meant to serre for their twelre jears, but it 8 by 15 per cent. the quantity of those who remained on for after their 12th jear. Now this was not exactly what the G desired, as ciril posts and not pensions or bounties are the : lass out for its non-commissioned officers. Accordingly a $p$ brought in March, 1877, before the Federal Council, by the I of the Empire, by which employment in private railways sk be given to soldiers having the necessary certificates, and $T$ lenst thirty-fire years old, and healthy in body and mind, in to others. The project continues, that these military candi not bo subjected to sererer tests than others in considering $\mathrm{tl}$ and if they have to give up their duties throngh incapa firmity, they shall be entitled to the pension which the rai] pany gives. Also that no bye-laws or regulations shall be enacts anything unfayourable to military errployés; and getting one of these situations, an old non-commissioned exchange his certificate for a óth class pension accordi: military rank he held on quitting the army, unless he is that pension, or to a higher one for other reasons. It is hol means to get a sufficient number of berths for the requirem German Army. It is estimated that 127 non-commission per corps leave with a certificato erery ycar; adding 60 for and 418 for the police (they hare certificates after nine yeas and excluding Bavaria, this makes a total of 2,510 , or 3,00 most, requiring situations. By the project of .Mrarch, IE posts are said to be thrown open to the Army, out of which

1,884 jield a jearly salary of 1,500 marks and npw: 2,473 " " "from 1,200 to 1,500 marks

$6,172 \quad " \quad$ " " "from 900 to 1,200 ." and $18,700 "$ " " $"$ of 900 marks.

Probably a large number are not very raluable, but all con societies are obliged to advertise in the Dilitai-Wocher racancies they have, so as to allow non-commissioned o ccrtificates to see what is in the market, and to apply.fo they consider suitable.

Notwithstanding all that has been done, there has been ficiensy in old and really efficient non-commissioned officer: more legislation may be required. Will the Germans persi their industrial enterprise, and force a certain class of empl or will they raise a fund as fairly as they can from that $p c$ Empire which contributes least to their military establish: give bounties to their old servants? Within the last $f_{f}$ 
howerer, an improvement has been observed, and non-ce officers do not appear to be so difficult to keep, as w formerly; this is due almost entirely to the depression in at present exists in North Germany. This fact will doul the Government for the present to withhold any further $r$

Quite recently a new military grade has been created, webel-Lieutenant, holding a subordinate position among th the Landwehr, and ranking between $a$ Cadet and $a$ These posts are to be filled by .old non-commissioned offic in good circumstances and otherwise fit for the position. after Second Lieutenant, and can join their regiments wi balloted for ; they are cxempt from the courts of honour, of a commission (Palent) they receive a warrant (Bestall: ing to tho custom followed in the cases of the Feldwebel o Their duties are those of Officers, but their pay is not. Cabinet order by which they were created.

\section{France.}

France can hardly be said to have altogether recovered the war of 1870-71, which upset all her military instita rcconstracting hersclf gradually, and laws regulating $t$ non-commissioned officers aro expected, but not yet pas over, she is a rich country with a flourishing trade, an manufactures, and her difficulties with regard to the qut fore are all the greater. The rules at present in force $\mathrm{dc}$ their object, for the inducements offered are not sufficient. bonnties were given to re-engaged men, and this answel well, bat as they have been done away with, good non-c officers are all the more difficult to be got. In 1873 there French Army, exclnsive of 82 depôts, 494 battalions; or or little more than 1 per battalion re-engaged for 5 years. the case, the French Government is obliged to promote sc they havo finished their first term of service, and thus $t$ missioned officers are too young and inexperienced. The July, 1874, to take effect the 1st Jannary following, enc rectify this state of things. It provided that the pay should to tho following:-A regimental sergeant-major, infantry, in the artillery, 3.25 francs per day; pay-sergeants, ir francs; artillery, 2.60 francs; a sergeant, $1 \cdot 10$ francs, a francs. Re-engaged non-commissioned officers to receive of 30 centimes daily, and after 10 years' service an extra After 15 years' service, or 35 jears of age, a pension i reckoned according to a particular proportion, in such a for each year of service and each campaign $\frac{x}{35}$ of the ful 25 jenrs' service is given; provided that the sum of the pe: pay of a Gorernment situation shall not exceed 1,200 f 12 years' service, four of which must have been spent a missioned oflicer, they may receive appointments ir serrice, post offices, telegraphs, railways, and public officr 
has not answered the expectations of the framers, and still not remain in the Army.

The education given to French non-commissoned officers improved, but it is not jet on an altogether satisfactory These are trained merely in the regimental schools whi in every regiment of infantry, cavalry, and artillery, b cient time is not given to learn much. These schools arc into three, viz, those of the 1st, 2nd, and 3rd degree. T of the 1st degreo is quite elementary, it exists in every c squadron, and battery under the captain; it confines itself ing, writing, and arithmetic as far as the four rules; the are anpaid, and the instruction is obligatory on all soldiers quainted with these subjects. It lasts an hour a day at winter, two hours if possible. The schools of the $2 \mathrm{ni}$ embrace German, arithmetic, general ideas of geography minor operations of war; these are instituted for corporals motion, also for sergeants and one-jear roluntecrs. The co one year, but the instraction is only given twice a week, $1 \frac{1}{2}$ hours each time. Those of the 3rd degree teach French 1 tion and dictation), arithmetic, history, geography, elements geometry, reading maps, field fortification. The attendan latter is roluntary, it is for non-commissioned officers and volunteers; no man can be recommended for the rank of Sub-I from the ranks, unless he has passed the 3rd degree school, that he knows as much as he could learn there. In 1875, mo improvement took place, and a school- "Ecole d'essai des . "troupe" - was established at Bambouillet, and an attempt mad in institution for the purpose of training non-commissioned ، the manner done in Germany and Italy. Boys on the stre corps, and recommended by the General in command, to the 600 , are admitted; 30 of these must pay, but the remaindes Great opposition has been made against opening it to any except those of soldiers, and this is at present the rule. Ti mental school has not proved a failure, and it is probable only will it be reckoned soon among the permanent insti the country, but that others will also be founded for the sam The "Ecole d'application de Cavalerie," at Saumur, also ti non-commissioned officers, and some of the men to become $i$ in the cavalry, artillery, and train, the former as Officers, as sergeants. The course of the first lasts a jear, and c the final examination they are promoted to a commission : on the first vacancies. The course of the second lasts 1 and comprises cavalry regulations, rough riding, veterina: military legislation, artillery, fortification, military art, tc and German ; at the end of 6 months, on passing an exami: student is made a corporal, at the end of another $6 \mathrm{mc}$ third on the top of the list are promoted sergeants, the ren leaving the school. The school at Saumur is also open Officers who go through conrses of instruction. Finally the schools through which sergeants can be promoted to co 
(1) that at Tincennes for the administrative branches of and (2) that at Bourges ("Ecole de Sous-Officiers d'infante (with very few exceptions) who wish to rise from the ran through this school ; the course lasts one year; the number is generally 400 , but it must not exceed 4.50 . This sc affects the commissioned ranks of the French Army rath others, is not jet considered by some to be on the best possi There are too many students, and thus all do not get theil at once on leaving, but have to wait sometimes two or 1 eren when high up on the list. The educational standard enough, and men who hare not sufficient general inowledg' allowed to pass. Candidates with greater qualifications in number may, perhaps, for the future, be the only ones a

General Rochebouët, for a short time War Minister, has ] December last, to take effect 1st January, 1878) placed 1 education of the French Army, comprising all relating $t_{4}$ missioned officers, \&c., under a now lureau. The busin office is now conducted by an infantry Officer, assisted by $t$ Officers and clerks. Some new regulations for non-co: officers are expected; but the political erents which took ] country last year have required so much attention in anothe that nothing has hitherto been done. It appears, hov Gencral Garnier, who now commands the 8th Army Cor short time ago was nnder General Ducrot, has been empl Gorernment to draw up a project to solvo the non-co officers' difficalty. A committee of twenty-two members . in the late French Chamber was formed to inquire into $t$ and a proposal was also made by a sub-committee and $p$ General de Chanal. This latter includes the following poi:

(1.) Restrictions to the-one year volunteer system.

Public opinion in France has been rery hostile to this ensing a certain portion of the community of their milita It is considered to be liable to abuse, and to be another $f_{1}$ the old state of things, which cansed so much harm to $t$ Moreorer the one-year volunteers form the very class from best non-commissioned officers should come, and thus it i of General de Chanal to diminish their number. He w those with unirersity degrees still to perform this short those who get the advantage by an examination alone, sh numerous, and reduced to 2 per cent. only of tho previons tingent. 'Thus, instead of 9,500 one-year rolunteers, he I but 3,000 , or 2,500 with a unirersity degree, and 500 a examination.

(2.) Voluntary serrice might commence at 17 years of candidate were physically fit.

(3.) The formation of non-commissioned officers' schor regiment, or battalion separately administered.

This school should bo organized as a company, but. in cas zation it is to be done away with. Men likely to make commissioned officers are taken, and their promotion del

VOL. XXII. 
their aptitude and morit. Every year also the smarte attained the rank of sergeant-major may compete for ad the Military College to become Officers. This rule is General de Chanal as being necessary, so that all the $\mathrm{O}$ Army shall be of one origin (that is from the ranks); br pointed out that he really only insists on two-thirds of $t$. the candidates coming from that source.

(4.) Civil posts.

The principle ennnciated is that having scrved t1 term, nothing is to be expected from the State; but gain the adrantages of employment by the civil auth extra service must be performed. Consequently the s that all those who desire to get any place whaterer State, must hare served the country, by haring been an having obtained a degree in the schools of medicine, ag: or by having been a non-commissioned officer for fou having been a corporal or soldier three years bejond $t$ term. There are some exceptions to this rule, probabl. those who could not serre in the Army,

(5.) High pay and annuities.

Erery non-commissioned officer and soldier can reto 5 years beyond his obligatory term under tho colo do so when he has served one year, and thereby he extra daily pay of 10 centimes if a private, and $I_{\text {? }}$ abore that rank. A second torm of re-engagement is with the consent of the Commanding Officer, in wl extra pas is doubled. Besides, men who are permitt in the serrice five years after their compnlsory terr annuity of 15 fr. the first year, increasing $10 \mathrm{fr}$. each $\mathrm{y}$ maining four years of their re-engagement, if corporals and if above that rank $30 \mathrm{fr}$. first Jear, increasing $20 \mathrm{fr}$. are procured from a capital which is granted by the St: is not pasable to the man until he leares the Army. engagement is allowed, and the same advantages as in 1 giren. Those who sell their reversion of these sams or $i$ are broken, aud thereby lose all right to them. A th ment is also allowed on application to the Minister of no extra pay or annuity. At the end of 15 Jcars' servic this plan a man would be entitled to a sum of $2,200 \mathrm{fr}$. commissioned officer to $4,400 \mathrm{fr}$. (£176).

(6.) Position of non-commissioned officers.

Facilities for marriago are given. Reduction to the i be cffected by a Ministerial order, or by the General of $\mathrm{F}$ of corporals.

M. Laisant, a Member of the Chamber of Deputies forward, in Norember, 1876, a scheme which was $r$ Committce already mentioned, bat there has been no c discussing it as yet; and accordingly he has again pres present Chamber. He aims at giving non-commissionc have prored their worth, and have remained in the se] 
a certain real status held by a certificato bestowing upon manent grado-il recevra wne commission en vertu de laquelle mopriétaive du grade de Sous-Oficier. Le grade conféré par de la République constitue l'état de Sous-Officier commission position cannot be forfeited except on account of certain cri another rank is:created, "premier sergent." Again, it is pr the pay should be the same in every branch of the Army, increase with the service of the soldier. This is rated as Adjudants (battalion sergeant-majors), np to 3 years'servic per diem; after 3 years, $2 \mathrm{fr}$. $45 \mathrm{c}$.; after 6 jears, $2 \mathrm{fr}$. 9 years, 2 fr. 80 c.; after 12 years, 3 f.; after 15 years, 3 fr. 20 years, $3 \mathrm{fr} .60 \mathrm{c}$. The other ranks in proportion, comme the following: (for men under 3 jears' service) serk $1 \mathrm{fr} .40 \mathrm{c.}$, premier sergent 1 . fr. 15 c., sergeant $1 \mathrm{fr}$, and nearly in the same manner as the pay of the adjudant. Aft a pension is obtainable, from 600 to $700 \mathrm{fr}$. yearly, accor grade of the man; this pension is increased by 10 fr. for $c$ service or campaign after the 20 years. All those who ha cate of permanent grade (Sous-Officier commissioné) have : pension, if they are invalided in the service of the coun 9 years' service (4 a non-commissioned officer) a soldier ca] situation in civil life; his application goes in, and he co: duty until a racancy occurs; he then tries the post for 1 being still kept on in the Army; should he be found fit $f$ he consents to undertake it, he is struck off the list of the ro not he returns to his duty. It is also contemplated by I scheme to extend the list of posts for which old soldiers are av this should: embrace those on the lines of railway (belongin: companies). Finally, there is a hope expressed that non-co officers shall be made as comfortable as possible, more espe who have their certificates of permanent grado; they shoul maxry, and a mess (cercle) should be established, besides ] their convenience and instruction. This project still cc promotion from the ranks; it confesses that the rank of $\mathrm{Ca}$ highest which, as a rule, a non-commissioned officer can a is proposed that its pay be increased, as it is not sufficier make young men caro for the position it offers.

General Berthant, late Minister of War, also presentec to the Chambers in 1877; and this is the one which the adopted. In this project the legal.status of the non-commissi is objected to, because, first, it is a mere ideal advantag' material equivalent; and because, secondly, it might make $n$ sioned officers somewhat too independent of their chicfs. time it is conceded that in the Army Regulations a definite $q$ sort may be granted, but that this should not be done by ste commissioned officers allowed to re-engage, have a sum $p$ credit, rated at 600 francs for each of the first four years in serve as re-engaged men. A sixth of that mones, or less, ma them as a bounty when it becomes due ; the remainder (or 1 the bounty is not claimed) is placed in the Funds, and yiolds 
to them. The right to sell out is only given when service. In case of death with the regiment, the widor reccires the full sum of money which should be in th 2,400 fr.) For wounds or disease contracted in the pub] man receires the same amount, and in case of promotion sion, or an appointment out of the Army, a proportional p: A proportional part only is also given to those who have otherwise than is mentioned above; those who are reducer hare a right only to the money carned at the time they c fault, the permission howerer to sell out of the Fun granted on the completion of their four yenrs' re-engago - Instead of the provisions as to extra pay and pen quoted from the law of the 10th July, 1874, non-commist according to General Berthaut's scheme, are to get an i centimes per diem after 9 years' service, and a pension : service, whose rate is reckoned for each year and for ea at $\frac{1}{25}$ th of the full pension due after 25 jears in the employments are also to be open to non-commissioned o is reckoned by General Berthaut that his project will gis re-engaged soldiers per jear. The Minister would, of the right to reduce this number according to the requir country.

The French military world is natarally deroting muc this question (as well as to those plans for the reduction $c$ sory term of service from five to three years, and for the : the one-year volunteers), and many are the opinions Space would not, however, permit us to repeat these val Suffice it to say, that most tend to the plen of giving a 1 certain number of years' service, as the best means of to re-engage, as giving them the greatest possible facilit; work when they leave the Army, and as not interfe: industry of the land. Fer proposals, howerer, hare bee as to a special fund for the payment. of these bountif respect the tendency in France is not the same (as will 1 Italy. According to the schemes already mentioned, been said about this; the money required, being raise bndget. One scheme by a general Officer, adrocating : mas be perhaps touched upon in conclusion. He c during the first term of serrice, non-commissioned 0 belong to the 2nd class; afterwards (re-engagement fo: the lst class; during this latter period they receive e tinctions in their uniform, and better barrack accommodi end. of this re-engagement (12 years' service) they $s$ annuity for life of 300 francs. Should they desire to rethey may do so for another 5 years, and at the end serrice, receire an annuity of 500 francs for life. If moted to Sub-Lieutenant during the second term of re-cn: they still retain the 300 franes pension. This money is from the fines payable by one-year volunteers. 


\section{Austria.}

In the Austrian Army non-commissioned officers are obtai:

(1.) By promotion from the rank and file. Intelligent and ducted men, those who are likely to be of use, are proms vacancies occur, provided they hare served the minimum down by regulation. No man may be a corporal until he $b_{i}$ the ranks six months as private, nor a sergeant (or sergea until he has served one year. For the training of privates, a: future instruction of those already promoted, regimental scb been established, and to these further reference will be mado

(2.) By direct appointment, on passing certain qualifying tions, after having been a student at one of the military ace the Empire. These institutions are mainly intended to ed sons of deserving but poor Officers, and in many cases the maintained free (or nearly free) of all expense to the parer of those whose military education is paid, must. sign an oblif be ratified by the parents or guardians), by which they agre a year above the legal term, for each year or part of a yea. school. Those who are semi.dependent on Government remain in the ranks half that extra time. Those that pay education have also to consent to one year's extra service,.if been four years or more at the school. The wholo period colours is, however, in no case to exceed 10 jears.

There are three of these schools, viz.:-(1.) The Military School (Afititär Ober-Realschule), a preparation to the Milit nical Academy, of which more will be said further on. Stu to remain at this Ober-Realschule for three jears, and in finis course they receive a certificate marked "excellent," " "Batisfictory.". Those in the highest class are sent to th Technical Academy as racancies occnr; those in the nex become non-commissioned officers in the artillery; and th lowest are made 1st class gunners. There are 450 pupils course includes German, French, Bohemian or Hungarian, physical sciences, geography, history, artillery, geometry, (2.) The Military Academy (Militär Academie für Neustad. preparatory school-tlie Military College. The object furnish a certain number of Officers to the infantry, rifles, ar there are 380 students; the course lasts four years; and th of education is much higher than that already given. pass are appointed Lieutenants, but those who fail enter tl: non-commissioned officers. (3.) The Mrilitary Technical (Militär Technische Academie) to which the best pupils of Realschule are sent. The instruction given is abont the sal in the Military Academy; there are 270 pupils, and the $c$ four years. Those that pass become Lieutenants, those th appointed non-commissioned officers.

The term General is applied to that portion of the schools which are destined to educate non.commissioned, men. There are four classes; the 1st class is divided 
sections, viz.:- $-(a$,$) instruction for the ordinary rank and$ for non-commissioned officers and those of the prirates lik promotion. The 2nd and 3rd classes include those that are special duties, as pioncers, drivers, hospital orderlies, polic geants. The 4th class is for one-year volunteers; this too into two sections, viz: :- $(a$,$) for those who qualify for no$ sioned officers; $(b$,$) for those who wish to become officers o$

The highest non-commissioned grade is Cadet, which ii aspirant to the rank of Officer. Men are appointed to this.] the War Minister (all other non-commissioned officers art the Commanding Officer), but they must either go through schools, or else present themselves at the final examination. and the standard of education in these schools are made me view to instruct an Officer than a non-commiseioned officer. great resemblance to the Younker schools in Russia.

The period of service in Austria is three years. Re-en are made after that. term for one year at a time, and th renewed with the consent of the Commanding Officer eigh until the man has 21 years' serrice. Re-engaged men re pay, which, however, does not increase with increase of se

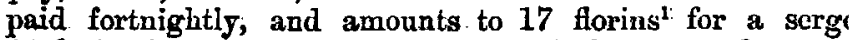
14 florins for a sergeent, and 9 florins 40 kreutzers for a cr month. Service with the colours, after the legal term 1 counts towards that in the Reserve, and afterwards in the Bounties are also paid, and these amount to $£ 6$ after the fi $£ 12$ after two years, to $£ 19$ after three years, to $£ 26$ after and to $£ 126$ after twelve years of re-engaged service. badges are, moreover, worn on the arm denoting good servi The money required to furnish this re-engaged pay: was in 1849 by fines payable by rolunteers. At that time a $\nabla$ additional sum was given to the men who remained on in 1 but the amount was.secured to them fur life, and in case . was convertible into 30 florins. 'A little later' the remplaç was introduced, and re-engaged men. were paid higher , capital thus raised. At the end of their service they bounty which varied between 1,000 and 1,500: florins. management a fund was created, which now forms the priur whence the extra rewards are given to non-commission Towards the end of the year 1857, however, the money so.a was used for other purposes, and did. not benefit, as.was-in subordinate portion of the commanding personnel of th Army; in that year 23;000,000 florins were diverted to I expenses, principally for the manufacture of war materis 1860 the first step was taken to settle the income deri permanent fund; and by this means the money in hand $\mathrm{l}$ increased, until the introduction of universal service withoul prevented it from receiving any more fines. The seme mi. lation obliged the Government also to reduce their re-eng: 
the amounts stated above. The fund created by the remplafa of the past, bears a jearly interest now of $1,279,926$ florins. 6,573 sergeant-majors, 11,361 sergennts, and 17,714 corpo re-engaged.men, and reccived the extra pay which was attach position; in round numbers, the amount of money required this was $1,900,000$ torins, leaving a surplus of 620,000 flor obtained elsewhere from the State. It is by no means certais fund will remain rintoached and arailable for its original $\mathrm{pr}$ lias once before been appropriated, and a want in the Treasur is now said to be folt) might be conreniently satisfied by it. other hand, all military opinion is convinced of the ne giving an allowance to re-engaged non-commissioned offic Austria has always adopted that system; if, therefore, th fund is done away with, something clse will, in all prob: established.

Pay in Austria is two-fold: Löhnung or actual wages, anc gell or that in lieu of rations, and payable every five days ir This latter varies according to the market prices of provisic is optional. whether the men take the allowance in mor. rations in kind. Tho Löhnung amounts to 15 kreutzers per corporal, 20 kreutzers for a sergeant, aud. 35 kreutzers for a major or a cadet; these latter have an allowance, called .Dien of 8 florins per month, and this is payable whether ther or not. The Menage-geld is not intended to cover bread, 1 lights and tobacco, which are provided otherwise.

In barracks corporals and sergeants live with the men, but majors, cadets, and one-year volunteers, have generally scpar: Non-commissioned officers are free to take their meals w like. As to marriage, 4 per cent. of the effective are on th of the regiment, and their families amenable to martial. I have quarters or an allowance; also when sick in hospital, o duty in peace, or when away in the field, the family gets the adrantages:-(1) One ration of bread for the wife, and ha' child, per day; (2) The menage-geld which the hasband.w: to; and (3) lodgings free. The remainder may get leare Commanding Officer to marry, but they have no privileg commissioned officers used to be allowed to remain out of $b$ long as they liked, without leave, after tattoo; but this pern been cancelled, because the men were not looked after, ar dulgence was found to be unduly great, giving occasion to irre

Punishments in the Austrian Army are as.follows :--Serge and Cadets may be (1) reprimanded, by word of mouth, in I in presence of all those of equal rank and those above them; may be stopped, or even. the offender may bo ordered to barracks at a. specificd hour betore tattoo, for 30 dass ; arrest, or open arrest for 30 days; (4) reduction to the ri having been formally warned (this punishment does. not : Cadet). Sergeants and corporals are subject to the same $\mathrm{pr}$ as the men, with tho exception that they cannot be awar hole, nor can they be "tied up." for 2 hours; they may, he 
reduced after formal warning. Strict arrest, to which they means imprisonment for 30 days, without hard labour; so finement can be extended to $\mathbf{2 1}$ days. All these punisb given without trial, but the most serere of them, e.g., redi the full term of imprisonment, can only be inflicted by 1 commanding the regiment.

Two corps of the Imperial Royal Guard are recruited smartest and best condacted non-commissioned officers of The Trabanten Body Guard, who reckon 48 soldicrs officers, \&c.), and the squadron of Life Guards, 60 in $\mathrm{nt}$ their men from this source. The engagement for these respectively three and four years; afterwards re-engagem year to year. Candidates must be under 35 years old to there is no limit to age when they must leave.

Promotion from the ranks, properly so called, can hardly exist in Austria. Many candidates for commissions hi through the different ranks of the Army, bat that is wi to training the Officer himself, not to reward the non-con officer who has proved limself smart and useful in his $\mathrm{s}$ sphere. A non-commissioned officer must be first appointe and go through the necessary examinations; he can the promoted, after all the Officers of his future regiment 1 their consent to allow him to be admitted among them, a every way fitted for his new position. In war time non-cen officers, who have distinguished themselves before the e1 who-have received the consent of the Officers of the reg eligible for promotion to a commission.

In Austria there are no pensions for long service, but a are enabled to receive civil appointments instead. In 187 \% laws were passed in Austria and in Hungary on this su these, men who bave been on the active list for twelve year which must be spent as a non-commissioned officer, and wl conducted, acquire a claim to be granted situations in the vice, railways, steam navigations, or other nndertakings, guaranteed or licensed by the State. Also, those have the same who have been injured in war time, or in the execution of po and who are therefore unfit for military service, but still c undertake civil employment. Civilian candidates are not compete, if there is a military applicant requiring the post, manifestly unfit for it. From time to time lists are publish the vacancies which occur in the civil administration of th also the time within which the application must be made for one of these situations is given away illegally-that is having no military claim, when an army candidate was at appointment is declared null, and has to be given up, exce has been held for one year; in which case 100 to 500 florins a fine to the poor-box of the parish. When a licence is gi railway or steam boat company for the public traffic, the even when not guaranteed by the State, is bound by the a Another appointment; open to old non-commissioned of 
havo qualified themselves for civilian employment, is that of major of Landwehr district. The country is divided into company districts, and each has a sergeant-major or Bezirls Failing men of twelve years' service, those of ten years-or to the class which is just entering the Landwehr-may b This appointment is worth 600 florins per annum, and im 100 florins at the end of five years' service in the post; by : at the end of 10 ycars; and 300 florins after 15 years. $B_{1}$ pay, the Bezirks Feldwebel receives lodging allowance, only ferior to that to which a Sub.Lieutenant is entitlod.

The system above described does not seem to answer military authorities in the Fmpire are by no means exe trouble in the matter. Quoting from the Vedette, an Austs paper, the Bulletin de la Réunion des Officiers, of last Nover that the dearth in non-commissioned officers has never ber than in 1877; and that even re-engaged men leave the Arr as they can. This difficulty, it shonld be remembered also: more in Austria Proper, and in the richer provinces, than in Dalmatia, Croatia, Gallicia, \&ce, where trade and manufa not so flourishing. We have not, however, seen any propos remedying this state of things, and consequently it is im: conjecture what will be done, if the regulations now in fo attract men, to serve the State in the subordinate portion o manding personnel of the Army.

\section{Russia.}

Only a short time ago a sufficient number of old so] always to be found in Russia, from which to draw materi commissioned officers. Those that served in the Army w as it were, from their original homes; they lost their rights, and were often obliged to remain with the colours $c$ necessity. Provision seems to have been made for them; not sent away, and hence there was always an abundance promotion, men who looked to the Army alone as their ho the scene of their life's carcer. Thus the very elements ne good non-commissioned officers according to the old tyl hand. In 1867, however, soldiers were permitted to retain munal rights, and during the last fifteen years Russian have greatly increased, so that a peasant can now find wor was formerly impossible; thus it is that men having com: term of service, leave the ranks, to enter upon other wa Considering that the term of service was long-15 yearsnot have affected very seriously the cadic of non.commissio: had it not been that this also was reduced to five years in On acconnt of this change, Russia has also been obliged the recruitment and the reward of her non-commissioned c

There are two classes of non-commissioned officers.

(1.) Those who are illiterate, or nearly illiterate, from classes of society; and

(2.) Those that cau pass a certain qualifying examinati 
are either one-year rolunteers or have been drawn into lot. (In Russia it should be remembered there is unire tion without exemption; the War Minister, however, ds requirements of the jearly contingent, and this is taker remainder being drafted into the militia.)

The latter a ppear to be rather Cadets than non-commissi ther are promoted without vacancies, they have certain $\mathrm{F}$ better kept, and, as a rule, get promoted to commissions former class, non-commissioned officers, properly so calle as a rule only 8 to 10 per cent. of the recruits are : and thus it is necessary to send all those who are likely to a military school, and after two years' instruction, occurring, they are promoted to the rank of corporal ( $M$ Offizier). Non-commissioned officers in Russia receire clothing, billets, and barracks accommodation (this latter cient for the whole Army), but their pay is rather pocke anything else. It is pajable three times a jear, and amc

Inf. Car.

For a Sergeant-Major (Feldwebel) 24 roubles, 24 r., Sergeant (Starshiji Unter-Ojpizier). 18 " 18 " Corporal (Mladshiji Unter-Offizier) 4 r. 5 c., 4 r. 5 c.

In 1871 certain regulations were made by which nonofficers alone were permitted to re-engage after their obli (fire years), and if they did so it was at least to be for on pay for a feldzecbel 42 roubles, ${ }^{1}$ sergeant $30 \mathrm{r}$., and corporal was given to re-engaged men. In 1874, this extra pay to 84 roubles for a felducebel; and $60 \mathrm{r}$. for a sergeant corporal receiving nothing; and other rules were pablis usefal soldiers (musicians, clerks, \&c.), as well as non. officers, can be re-engaged at least for ono year. They c: to the ranks from the Reserve, if they have not been me years (one jear for soldiers) away. Non-commissioned , their first fire years of re-engagement are entitled to a on their left arm, after the completion of this term th on wearing a gold chevron, after ten years they receive : on which is inscribed "for zeal," to be worn on the brc fifteen years a gold and silver medal, likewise having $t$ "zeal," to be hung round the neck. Again, after the 1 of re-engaged service, a man is entitled to a certificate : him to a civil employment.

In March, 1877; the last regulations wore issued, and

(1.) Men who have completed their first fire years service, and having received certificates of recommenda preferred to all others as candidates for employment i eren military administration of the Empire.

(2.) Non-commissioned officers in the receipt of ex they wish to leare, receive a bounty. of 250 roubles af

1 The silrez rouble is worth $3 s .2 d$. The present rouble is pap nished rory greatly in ralue; a rouble is equal to 100 copecks. 
re-cngaged service, and after twenty years a pension of 96 : year, or a bounty of 1,000 roubles paid down. If wounde lated in war or in the service of the country, the lesser bou after soven years, and the greater (or pension) after fift these are independent of any annuity which the committee $v$ on the, claims of the wounded may bestow. In case of widows of the above-mentioned men receive 36 roubles the.

(3.) Corporals who get no extra pay are cntitled to it moted, not only from that date, but for all their previous 1 service. They also receive the bounties (or pension) as abov they have been a year in the rank entitled to extra pay.

(4.) Non-commissioned officers, if they return to the co the Reserve, are permitted to count their former re-engage but those who leave after their tenth year and take $t$ ( 250 roubles) lose all right to the higher reward if they a the Army.

By these arrangements a man at about 35 is entitled $t$ 250 roubles and a chance of an employment in civil life, remains another ten years in the Army he is given a capita roubles, or a small pension. of. 98 roubles for life, when $b$ 45 years old. After five jears as non-commissioned offic may get leave to marry, in. which case quarters are usuall hisa, and a small allowance for his children, up to 14 yet boss and 10 for girls.

Above the sergeant-major (feldwebel) there is another ra Russian Army which is not commissioned, called Porte lipe Promotion to this grade can only be obtained by passing special school. The pay attached to it is 100 roubles a. $y^{\prime}$ appears to have certain privileges.

Younkers, or those passing tho nccessary examinations, : to rise from the ranks (we are dealing with the 1st class of missioned officers, viz., those that were enrolled as illiter having completed their period of active service, of which must be passed as a non-commissioned officer. These $\mathrm{C}$ usually posted to garrison troops, and their new position st far from a happy one as they often give up their comm which case they hare a special pay and wear the Younler silver. About two. per cent. of. the Russian Officers come source.

The regulations concerning civil posts are not yet fixed, end of those issued in March, 1877, the intention of forminy commission on the subject was announced. The war in $T$ of course, put an end to any such thing being carried out; is almost impossible to say what will be the effect of these $t$ the question under consideration. We are informed, howev Russia there are about 80,000 posts in the civil administrat Empire in the gift of the Government, with salaries var. 85 roubles to 700 roubles per jear. No qualification is (except an elementary education, and a good character for those worth 240 roubles. In order to obtain the others wit] 
pay, a good hand, technical bnowledge, and quickness in : necessary.

If the war does not shake the stability of the Russi organization, it remains to be seen how these new rules Hitherto, re-engagements have been insufficient-only $c$ sergeant-majors, and fourteen per cent. of the sergeants beinc men;-this may be due to the quiet and unaspiring ta Muscovite peasant, who is no longer cat off from his hor serving the Czar, and who prefers his nnobtrusive poverty service. On the other hand, these are the first attempts the future comfort of old soldiers, and as soon as the regu had time to work, and time to bestow certain bounties, as . salaries upon those who shall become entitled to them, Army may be supplied with as good material for non-ce officers as the country affords.

\section{Denmark.}

Denmark, as a military nation, is insignificant when col the larger Powers of Europe; her position is, however, s portance; and, surrounded as she is by far more powerfu] military system has been organized more with a view to ? to offence. Ont of a population of something unde souls, Denmark's forces on a war footing may be cousides 45,000 men, of whom 25,000 belong to the line, 10,000 to and 10,000 to the augmentation. During peace time, onl are retained for military instruction; and, during the wir 6,000 of these-chosen by lot among those who have pas their drills satisfactorily-are sent to their homes, leari men for garrisons, \&c.

- The Danish Army is divided into brigades, each comp demi-brigades (two battalions). The yearly contingent 0 sent alternately to the two battalions forming the demithus each of the former receives its recruits only every two men join in April for six months, and out of their nuu per battalion are chosen for the corporals' schools, and one remainder for the lance-corporals' schools. For admiss former, an elementary examination is required in subjec taught in the first class national schools. These men are lance-corporals, and remain at school during the wint. following April; they are then transferred to the other the demi-brigades, and instruct the fresh batch of recruits liminary work. Afterwards they return to their old batte period of training under canvas, and then, if considered promoted to the rank of corporal by the battalion comm may be then sent home on furlough, or kept on dnty, acce requirements of the Service. In each cavalry regiment $6 \mathrm{yr}$ selected for the corporals' school, 8 for the lance-corpr In the Artillery, 87 gunners and 18 drivers for the former and 20 drirers for the latter. 
There are three divisions in the commanding personnel ( $\nabla$ and non-commissioned officers) of the Danish Army :-

1st. Those in temporary employment, viz., Second Lieut corporals and lance-corporals.

Ind. Those on permanent duty, viz., Generals, Colonels, $\mathrm{Ca}$ First Licutenants, and staff sercreants, sergeant-majors, and

$3 \mathrm{rd}$. Those on the augmentation, viz., same as in the $2 \mathrm{nd}$

On a war footing a battalion must hare 36 corporals, but footing 18 are considered sufficient. Men on promotion tc if kept at duty, are retained for periods of serrice extending (or sometimes two years, if the first period). Sergennts are by the battalion commander from the grade of corporal, bul not be over 32 years old; on this promotion, they pass from employment to permanent duty. Two jears as sergeant, necessary to qualify to become sergeant-major, and anothes to become staff sergeant; the latter of these appointments: the Brigadier. Non-commissioned officers are placed ints mentation on completion of their line service. Corporal sometimes be promoted from their regiments to sergeants 0 :

There are several schools established with a view to tra commissioned officers. 'The first of these is the Elementary which boys between 14 and 16, who are physically fit, are $\varepsilon$ examination on the subjects taught in the lower national s contains 120 pupils, divided into three classes, and the st kept a year in each of these. 'The school bears some resemb: earlier forms of the German non-commissioned officers' sc organized into an infantry company, having a Captain as cc and two Lieutenants, together with six staff and other serge: three arms of the Service) as instructors; there is also a ci master and two civilian assistants. The pupils are lodged, $f$ and cducated free; and their instruction comprises elemen ledge, both technical and general, as well as practical lenving, they enter the Army as privates; and, althoug for non-commissioned officers, they have no title to that $r$ they are quite qualified for it; they hare to go througl course as the other men, and if they fail to pass the entranc tion for the corporals' school, they have to do duty as comm Those that pass are, howerer, held to remain under the colo commissioned officers for two years.

The next educational institution includes the corporals' corporals' schools; in the infantry they are established in brigade under a Captain, three Lientenants of at least twe rice, one staff sergeant, and eight sergeants of the batta turn it is to form the school that year; all the Second Lie the other battalion act as instructors. In the cavalry, ar engineers, there is only one school for each. Those who a ciently qualified for the corporals' school become candida lance-corporals' school, but both are combined into one est except in the cavalry, where each regiment has one of the $]$ course of instruction in the infantry lasts $5 \frac{1}{2}$ months, in 
$7 \frac{1}{2}$ months, in the artillery 8 months, and in the engi it comprises drill, and all that which is necessary for charge of a non-commissioned officer's duties. It $\mathrm{e}$ examination, and entitles a pupil to be promoted-if satisfactory certificate from his Commanding Officer : for duty-when the has completed his serrice as Seniority is determined by the result of the final cxam that fail are sent home in their lance rank.

There are also sergeants' schnols, for the parpose those who are retained for "permanent daty." "I ments are similar to those just described, and in artillery they are combined with them; the conrse : the same time, and the instruction is both practical. It does not appear that it is necessury to go througl order to qualify for a sergeant's stripes, but preferen giren to those who have passed the final examination.

Non-commissioned officers have facilities for being $\mathrm{pr}$ missions. After passing the corporals' school, applicatic WarMinister to go through the lower class of the Officers passed this conrse successfully (it lasts thirty weeks), return to their battalions to undergo a practical test; if $f$ factors, they are promoted by the War Minister to the Lieutenant, on "temporary employment." "They are $t$ on furlough, or retained for a minimum period of one $y$ duty, in the same way as corporals. For promotion $t_{1}$ on "permanent dnty," Second lieutenants must pass third classes of the Officers'scliool, and obtain from the Officers a certificate of being qualified for the rank. step in the real commissioned ranks of the actire a volunteer commences his career at the earliest pos 18 years old - the compulsory age being 22-and gets a possible through the different schools of military inst be a First Lieutenant at 23 jears of age. The appointr on "permanent duty" is made by tho King; the can under 32 years old; promotion takes place afterwards 1 selection and seniority, and Officers must have been at time in each grade before they get their next step. Afi they are disqualified for advancement. Non-commissior are given commissions in the Augmentation, and prome sergeant to Lieutenant, and so on. If a man finishes hi Angmentation, he may be re-appointed to it with a Appointments, \&c., in this portion of the Danish Arm by the Brigadier, but made by the King in the case c Captains; by the War Minister in the case of Lieutena Brigadier for non-commissioned officers.

The Officers' school, throngh which it is neceseary fi in order to be promoted, is divided into four classes. the lowest is to train non-commissioned officers to becom tenants. It contains 63 pupils for the infantry, 19 for for the artillery, and 3 for the engineers. The course . 
September till the following 25 th April, and includes Danish mathematics, strategy and tactics, drawing, artillery, fo reconnaissance, and drill. The 2nd class is a preparation $f_{1}$ the final examication of the former being tho entrance to The instruction in the 2nd class is purely theoretical, and it for candidates to miss it, by passing direct into the nest appears, therefore, that it is established merely as a means , ting unedncated men to qualify themselves in the higher required for the rank of an Officer on "permanent dnt5." T] tion in the 3rd class embraces military sabjects, and the $c$ one year in the 2 nd class, two jears in the 3rd class. I senior class of the Officers' school is for the Staff.

Non-commissioned officers are entitled to pensions after bz pleted an active service of 20 years; this pension increase. man's service until he has been with the colours 40 year. varies with the rank of the individual, who, to get the allow: grade, must have served three jears in it. The pension of non-commissioned officer (staff-sergeant) after 20 years is $f$ per annum; after 40 years it is $£ 337 s$. $2 d$. That of a serg is $£ 11$ for the shorter term, and rises to $£ 2511 s$. $3 d$. for $t$ scrgeant, $£ 8.18 s$. $4 d$. and $£ 20$ 3s.; corporal, $£ 715 s$ t16 13s. 10 .; lance-corporal, $\& 6$ 14s. and $£ 136 s$. $4 \frac{1}{2} d$.; private, $£ 5.11 s$. $3 d$. and $\$ 114$. $3 d$. Officers also recciv calculated according to their service; these amount to ono-ter pay if under two years' service, but increase gradually to tw the arerage rate of their pas (during the tive years prec charge) if they lave 20 years' service and over. In er campaign reckons as two year's' service.

Invalid pensions are alsi accorded to the wholo Danish $A$ the injury has arisen by the performance of military duty; allowances may be made permanent or only for a year at a tin tain cases the invalid, if in Officer, retires on full pay; no sioned officers ard men receire a sum varying up to $£ 22$, ac rank, and according to the nature of the injury, in addit ordinary pension if over 20 years' service, or to a smaller a under that period. When illness not due to the Service inva these sums are diminished; but in special cases they are Widows of Officers and their children, up to 18 years old, are a small pensions when the husband was himself in receipt of, for, a pension; in the case of non-commissioned officers an widows and children, up to 15 .years old, are in all cases allor minual sum.

Non-commissioned officers are enabled to marry, with $]$ their Commanding Officers; , but they must be 25 years old, conduct, and have sufficient means to support a family. corporal marry on these terms, he is not permitted to rise fession, but is compulsorily sent home at the conclusion of ] duty. In fact, no unan on temporary employment who mars znitted to go upon permanent. lutty.

Second Lieutenants attor one year's service as such, are 
posts in the customs, telegraph and post offices, or to be superintendents, \&c., in the Royal palaces, \&c. Corpo served two years after passing the corporals' school hav claim. Permanently posted non-commissioned officers, aft service, may be employed under town councils as warder police, \&c.

\section{Sweden.}

In Sweden there are upper and lower schools for the $\epsilon$ non-commissioned officers of the infantry and cavalry. $T$. preparatory schools, are established regimentally, every bat ing 10 men for instruction. The course lasts 42 days, a reading, writing, arithmetic (including fractions), and former, or non-commissioned officers' schools, are two in $\mathbf{n}$ one at Fort Karlsborg for infantry, and the other at Stc cavalry. They are divided into threo classes; 1st class is men for the rank of corporal, 2nd class above that rank, a: (the senior) is to teach those men of any rank who aro adranced to profit by its instruction. The courso lasts 12 includes reading, writing, arithmetic, geometry, art of $\mathrm{I}$ field fortification, surveying, instruction in elements surgery, and drill. Promotion takes place as vacancies the candidate has received a certiticate as having passed the examination of his class, and after his ability has practically at the regimental head-quarters.

Edncation for the artillery is in the hands of the $i$ department of each regiment, and is under the superinte Captain and a Lieutenant. There are two sections; the corporals and non-commissioned officers, the senior for tho: for the Officers' school. The junior section is divided classes; a certificate in the 1st class is necessary for app lance-corporal; one in the 2nd class as corporal or sergea: in the 3rd class as sergeant-major. In erery case the $\mathrm{n}$ pass through a practical course of instruction; and $t$ ] promoted unless they show that they are proficient in thi in their theoretical studies; which compriso reading, $\mathrm{wr}$ metic, artillery, geometry, mechanics, fortification, and d the engineers a similar plan to that in the artillery is a instead there are five classes, viz., preparatory class for $t$ file, 1st class, to qualify for the rank of lance-corporal, 2 , that of corporal, 3rd class for that of scrgeant, and 4th $c$. of sergeant-major. Instruction is progressive, beginning $i$ class with the most elementary sabjects, and ending $w$ geometry, trigonometry, mechanies, fortification, architect

Men must have 18 months' service before they can be : the rank of sergeant, except those who have passed $t$. examination into the Cadet College, in which case they moted in 8 montlus. The instruction in this college is technical, and students are taken from the ranks of the Ar course they must have tho necessary qualifications to beec 
This is the only way in which commissions are obtained is for the law is now virtually obsolete which permitted no sioned officers of six years' service, two of them as sergeant be promoted without examination.

Regiments have private chests, ont of which Officers and missioned oflicers are pensioned.

The term of service is six years with the colours and six $y$. Landwehr, but the whole Army is not cmbodied except i manoourres.

\section{Noruay.}

Non-commissioned officers in Norway are divided into $t$ -those definitely, and those tomporarily, appointed. Bo cruited from the rank and file, if they are qualified $f_{i}$ tion. Those intended for the 2nd class aro educated for tion (corporals or sergeants) by a course of instruction, or ten weeks, at the depôt. Those who aspire to the have to go through a longer period of instruction; they $\mathrm{m}$ privates six months, then go through the recruits' sc then they can be appointed corporals. Afterwards they 1 through a two years' course at the non-commissioned offict and are then eligible for the rank of sergeant. There is or schools for each arm of the service in Christiania. Accor! manner in which he passes out of the highest class, a stui mitted to compete for admission to the senior division $c$ (Officers') School; provided he has at least served for $o$ sergeant in the Army, is not over 25 years of age, and $h$ a sound classical education. By the law of May, 1866, $t$ service was fixed at 10 years; 5 of them under the colou Reserve, and 3 in the Landwehr. Substitution was allower the Landwehr, which, howerer, could only be called out invasion. In 1876 a now law abolished substitution and $t]$ the periods of service were also fixed at 7 years for the ac and 3 years for the Landwehr. The duty is very light, the only embodied 80 days their first year; and afterwards $30 \mathrm{i}$ is all they have to do.

Those who rolunteer for 5 years, and who having com period are afterwards free, perform the necessary garrison Non-commissioned officers who have served 20 years are e pension, and those who have served 6 years on garrison $d u$ general dut5, have a claim to a civil appointment.

\section{Belgium.}

The Franco-German TVar in 1870-71 obliged the I mobilise their forces. Their system, based on that of $F$ equally inefficient when it camo to be tested practically. 104,000 men, which were counted upon in 1870, only 72,000 coming, and out of these 21,000 were remplaçant. This w sidered satisfactory, and a mised commission mas appointec into the question of Army reform; but as the panic of war s

rOL. XXII. 
labours of the commission were neglected, and thus, while tinental nation has re-modelled its military institutions Prrssian tJpe, Belgium alone still retains the old form defence. The difficulty of change is doubtless due to the, enterprise of the people ; for those countries who are wedde trial pursuits cannot easily be converted into military account of the bigh rate of wages. The non-commission question in Belgium under the present system is by no mea tory, and evers dny it becomes more serious; indeed, notw' the advantages offered to a young man of good character an talent, it is found rery difficult to keep up the standard of moted from the ranks, and this is eren said to be deteriorati a reformed system, in accordance with modern military $j$ difficulties would be increased, unless a special plan were meet them. A complaint which seems generally made : manner in which non-commissioned officers are lodged, will $\mathrm{p}$ ceire attention and be rectified. Old soldiers are not entitled: to situations in the civil administration of the country after l, of serrice, but although this is also recommended by ma question whether such a plan would altogether suit a mar country.

As to the system of military education in Belgium, whic been perfected in the last fow years, there are-

(1.) Regimental schools, often located away from their in which elementary education is given for one or two yee likely to become good non-commissioned officers.

(2.) On appointment, they may go through a courso of lasting two years, and embracing French, Flemish, arithme (as far as quadratic equations), Euclid, geography, histors, fication, and drawing. This qualifies for the higher schoo commissioned officers do not go through this course, and under 30 , they must attend evening classes, to be taught clementary geography and histors.

(3.) The highest non-commissioned officers' school is tha candidates from the ranks for commissions. This was est 1871 , and the instruction is said to be the minimam requir is an entrance and a final examination, and men may go latter without going through the whole course.

Promotion from the ranks takes place easily in Belginu there is sometimes a difficulty in getting active Officers in ranks by seniority; moreover, as has been remarked, the : Ofieers thus obtained cannot be maintained high. There therefore, that desire that this manner of rewarding non-cor officers should ccase.

General Thiébanlt, in his first triennial report on tho mili tion, hid before the Chambers 3rd June, 1874, says that education in the Army is satisfactory, but " the same canr " of tho middle and lower establishments; infortunately "material is not to be found there." Recruitment of vol consilers, leares much to be desired, as far as quantity ant 
concerned, and most non-commissioned officers leare the $A$ expiration of their engagement, in order to take the ad more lncrative employment in civil life. It is then difficul the Army with non-commissioned officers; instead, a lar of indifferent character take their place as such, and men i possess the necessary qualifications are all that can bo got.

\section{Italy.}

Italy is more advanced in the solution of the problem non-commissioned officers than any other Military Power. dereloped a system which, althongh not very long in forc answer; it requires only $a$ few years to perfect it and to $b$ : full operation. Italy, it must be remembered, has probabl culties to contend with in this question, than other nation: adopted obligatory military service; the country has no gr facturing or commercial industrics to render the Army such loss as it is elsewhere. The character of the people is not prising, and although many from necessity learo the coun work elsewhere, yet the majority if they can get just suffic at home, prefer to remain there. Indeed, in many parts of is by no means casy to be got, and this of conrse renders tions in the Army more popular than they would be wher trade competed in the labour markets. Comparatively spea Italy has little difficulty in solving for herself the questi commissioned officers; although the good results arrived at sent system are not altogether due to this, but also to the I have been drawn out.

The Italians divide their non-commissioned officers into I the superior, or those who are sergeants and above that ral inferior, or those who are corporals and do not rise higl trouble is taken about the latter; men out of the ranks con are promoted to these lower grades, and when their perioc is over thes retire, without any. claim on the State. T1 class, or Sott'Ufiziali, properly so called, are procured and $\mathbf{r}$ a very different manner.

All men who wish for promotion must engage to serve lasting eight years (the time as prirate or corporal being count). This is called taking the ferma permanente, and it very foundation of the Italian system; there is absolutely tion to the rule. Oring to this, the State can always ir the service of a serge:unt for about six ycars at least, and as of the ferma is not reduced should a man loso his strip ercry inducement for him to discharge his duty with rigilar of having to spend a weary eight years as a private under 1

Men of good conduct, of sufficiently strong constitution, : in their work, may re-engage for three years at a time Carabineers four times, the rest of the Army three time thes hare not passed the age of 40 for the former, and latter. The first of these re-engagements takes effect after the cight years' ferma, bat the Minister of War is emporrer 
the man to enjoy the extra pay which it brings, after six year provided almays that the man agrees to serve his extra th after the completion of the eight Jears' service. This ir engagement and secures the presence of a good non-com officer with the colours after his legal term is completed. engagements all have extra pay attached to them.

There are several winter schools in the Italian Army for $\mathrm{tl}$ tion of the men and non-commissioned officcrs; an elementar those who cannot read and write, a school for those who as corporals, in which grammar and arithmetic are taught; an for such as aspire to be sergeants, in which grammar, a elementary geography, and the reading of maps are tanght ciently good class of sergeant was however hardly to be expe the ranks; there was not sufficient leisure for training th became necessary to organize schools or battalions (squ batteries) of instraction, specially established for the purpos sating young men as non-commissioned officers. These wer in 1872-73-74. Three, viz., those at Maddaloni, Asti, and for infantry; one at Pignerol for cavalry; two at Pisa and ( field artillery; one at Genoa for garrison artillery; and to and Casale for engineers.

Candidates for these schools must-

(1.) Know how to read and write.

(2.) Enlist for 8 years (take the ferma permanente).

(3.) Be over 17 years and not more than 26 years old.

(4.) Be unmarried or widower without children.

(5.) Be sufficiently strong and tall.

(6.) Not have been previously rejected for the Army, o1 therein as a bad character.

They must further be provided with a document givins sent of their father, mother, or guardian to join the scl tificate of birth, and of good conduct from the civil auth from the military if formerly a soldier. On entry they ha and uniform of privates, their eight years' service counting instant; after six months, if they deserve it, they are promc rank of corporal with the pay. On completion of a year a. they are promoted to sergeant if they are considered fit, their regiments as such. Those who have been kept back a six more months to qualify themselves to receive the sergean but after these 24 montlis at school they must join their with whaterer rank they have attained to. If afterwarc not show sufficient capacity, or fail to satisfy their superic conduct, they are never promoted, while they are obliged $t$ their full eight years in the ranks.

These schools are organized as battalions, squadrons, anc with a fall complement of Officers and non-commissione The instruction given is both practical and theoretical; th cludes Italian, arithmetic, elementary geography, reading $\mathbf{0}$ : terior economy, elementary principles of military hygiene, a law, together with an easy method of texching recruits ho 
the former embraces drill, musketry, gymnastics, fencing, cial cure is taken that the pupils should be able to tea others; for this purpose they are accustomed to use the drill squads, and to go through all the necessary explana Army Regulations. The great object is to train instructor hare a thorough knowledge themselres of ercrgthing con the Service, and who can impart that knowledge to others. thoy are quite young, between 17 and 14 years old, and $\mathrm{m}$ succeed in passing their examinations to become corpc months, and sergeants in eighteen montls. In consequenc their regiments for the first time jounger eren than the called on to command: obligatory service commences : inconrenience of this has already been remarked upon. howerer, to prevent the Army being overrun with too I non-commissioned officers, which the resources of the pre would necessitate for the next few years, the Government the rank of corporal-major, giren to the best corporals really sergeants, although they havo not taken the ferma and are distinguished by red braid on the arm instead of $s$

Besides their ordinary pay, sergeants receive from the d promotion, a special extra pay (caposoldo) of 150 lire' per during each re-engagement an additional annual sum 150 lire. Thas if a non-commissioned offece signifies his re-engage, as we hare seen he can do, after six years' servi allowances per Jear amount to-

At the sehool......................... ]

When promoted sergeaut. . .................

1st re-engagement from beginning of 7 th year to

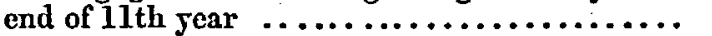

2nd re-engagement from beginning of 12th jear to end of 14 th year $\ldots \ldots \ldots \ldots \ldots \ldots \ldots \ldots$.

3 rd re-engagement from beginning of 15 th jear to end of 17 th year $\ldots \ldots \ldots \ldots \ldots \ldots \ldots \ldots$

4th (if in Royal Carabineers) re-engagement from beginning of 18th jear to end of 20 th year....

On leaving the Army he reccives coupons on the Nat yielding an income equal to $\frac{5}{5}$ ths of the extra pay erjoye of re-engagements, but not from the special allowance call so that on retiring after 11 years' service, this amount: after 14 years to 240 lire, after 17 years to 360 lire, and a (for the Royal Carabineers only) to 480 lire per annun take his discharge during the course of one of the above engagements, the amount of coupons are calculated onls $\frac{4}{5}$ ths of the re-engaged pay, for the periods he has comple leaving before the completion of his 17th ycar, he is on an income of 240 lire. Those, however, who are obliged $t_{1}$ any illness caused by the Service, are permitted to cou finished period as if completed.

1 A silrer lire is equal to a franc. 
By this means pensions cease to become chargeable to and pension offices are therefore dispensed with; mor holders of these incomes can dran them or sell out of th they wish to raise a small capital for present use, and these : are secured them without burdening the War Department business or tronble. Again, if a non-commissioned officer with the colours, his heirs receive coupons giving an incom the full amount of his re-engaged extra paj (not caposol his death was due to the Service, the broken period of re-e: is calculated as completed.

After 17 years' service (20 in Rojal Carabineers) non-con officers may remain on, if still fit for work: they cannot rereceive additional extra allowances, but they serve on for After 25 ycars' service (if 45 years' old) these are fixed at ' year for sergeant-majors, 415 lire for sergeants; afterwards, or campaign, adds 10 lire to it, until it reaches a maximum for sergeant-majors, and 565 lire for others, which sur obtained after 40 years' service.

After 12 years' service non-commissioned officers who discharge are helped in obtaining civil posts. These are? cially taken care of by the War Administration, and are cli named as Sub-Lientenants in the provincial militia. Genert mand of Army Corps are by a ministerial order of December, that a portion of their duty is to get those non-commissior who hare serred faithfully for twelve years, civil employment in the military administration, but in the railways, telegrapk February, 1872, the Minister of Public Works also drew a the necessity of employing them on the railways. There be no absolute right to $a$ situation, although a Parliamen mittee wished to make it so; everything, however, is done to men getting these employments, and from January, 1873 $1874,1,035$ were so emplojed.

Non-commissioned officers are treated very well and with sideration; and finally, they cannot lose their rank without ? by a court-martial (Commissione di Disciplina), composed of Colonel or Major as President, and four members, the findin inust be contirmed by the Lient.-General commanding the $d$

Re-engaged non-commissioned officers lose the extra pay to the actual period they are completing, when condemned it martial constituted as above. They may, however, leare $t$ as soon as their eight years is finished. They retain a ri income due from former periods of re-engagement (if anj when deserters, or when condemned to prison by criminal or by sentence of a military court, in which cases their suspended until they, have fuished the punishment inflicted.

Those non-commissioned officers who retire after their ei serrice pass at once into the territorial army; on mobilizat fore, there would be none in reserve to call up to fill the $4, C$ cies which would occur. This deficiency is made good by jear volunteers who obtain the grade of Reserve sergeant. 
there are about 400 of them, or 3.000 in the nine clas mobilised army. There will probably be more in future, mission to get transferred from the first to the second class tingent is now done away with (since 1st July, 1876), sllould be more one-jear volunteers in consequence.

Italian non-commissioned officers are often promoted to Officers. A school at MLodena is established expressly for $t$ ] and a certain number of men are selected each year by the regiments to go up for the entrance examination; these must have at least eighteen months' service as sergeant with If they pass, they go to Modona for another eighteen montk a second examination obtain a commission as Sub-Lieul taking adrantage of this regulation, a joung man may er lion of instruction at 17 years of ago, pass into his $x$ sergeant, and after serving as such for a year and a half, $c$ self for the school at Modena at 20, and finally become at $2 L \frac{1}{2}$ Jears old. The subsequent promotion of thes not bo rapid, as their education cannot naturally bo up $t$ it should be, and Captain in the Train will probably bo rank to which they can attain. The results, however, of cannot jet be pscertained, since it lias only been begun a ago. It is evidently an expensire process for obtaining ( State having to provide tho whole education of the together with their pay and maintenance for four years : the eighiteen months in the regiment can hardly. reckon service.

The ordinary pay is provided for by the War Budget, bn extra pay (caposoldo), and re-engaged pay, are met by $f$ military chost. This is managed by a committee, consist members, who choose their own president; riz., two senal deputies, elected by their respective chambers, two finan and two general officers, nominated by the president of . which thes belong, and by the War Minister respectively mittee changes with the Gorernment. The funds used to from two sources (1) from the fines of those. who paid ferred from the first to the second class of the annual con (2) of those who served as one-year volunteers. Since 1s no one can exchange military duty for money, and the fine .volunteers (viz., 1,600 lire for cavalry, 1,200 lire for $i$ consequently now the sole source of income. It is cal there are annually about 4,000 one-year volunteers, anc cent. enter the cavalry. Thus

By 320 one-year rolunteers for cavalry at 1,600 lire ... And 3,680 one-year volunteers for infantry at $12,000 \mathrm{lj}$

Or annually.................. Li

According to statistics there are 11,650 non-commissioner receire special extra pay (caposoldo), and this at 150 lire $\mathrm{e}$ to $1,747,500$ lire, which leaves a sum of $3,180,500$ liro e 
re-engaged pay. Should this source of income not be suffic still the means open for procuring more, by lerying mone: who cannot serre in person-like the old Bararian Wehrg

Such are a fow of the leading features of the Italian sy: supply of non-commissioned officers, and it is found to gir quantity for the requirements of the Army. Of course time gire thorongh proof of its value, and certain modificatio bably be necessary in its details. Its broad principles, ] sufficiently striking and important to make them worth consideration of those countries who are perplexed wit culties of the question. These principles seem to be-

(1.) Engagement for eight years for all who take the st

(2.) Inducements for re-engagement, viz., an increasine and a bounty on completion of service given in a conr to the recipient, and in a manner to lighten the duties Department.

(3.) Recognition of the principle that those who cant person, when universal conscription without exemption $i$ the land, shall be obliged if necessary to pay a tas for th the Army; this fund to bo deroted to the use of the co commissioned officers.

It will be useful to state, before finishing this subject, strengths in which non-commissioned officers are distrib Armies of Europe. The best idea of their relative impc be got by looking at the organization of a company and a regiment. The latter is the largest unit in which non-ce officers appear in the combatant strength of an Army (in $F$ Divisions those employed at head quarters being usually c while the former, in continental Armies, is a tactical unit c portance. In the following lists, the cadets are placed the sergeant-majors and sergennts aro classed as non-cc officers, properly so called; and finally also corporals corporals aro put by themselres. The importance of thes! bably raries in different Armies, but they are placed as ab purpose of comparison.

\section{England.}

A battalion on a rar strength contains :-

3 Field Officers, 25 Officers, 49 non-commissioned officers, 4 and 960 prirates.

\section{Germany.}

Company peace footing :-

4 Officers, '1 fahnerich, 6 non-commissioned officers, 20 co lance-corporals, and 106 men.

Company war footing:-

5 Officer, 1 fähnerich, 6 non-commissioned officers, 37 co lance-corporals, and 201 men.

A regiment is composed of 3 battalions of 4 companies regimental and battalion staff consist of:- 
5 Field Officers, 4 Officers, and 4 non-commissioned offic Regiment on a war footing is (not counting non-combato 5 Field Officers, 64 Officers, 12 fähnerichs, 76 non-co officers, 444 corporals and lance-corporals, and 2,288 men.

France.

Company peace footing:-

3 Officers, 6 non-commissioned officers, 8 corporals, $66 \mathrm{~m}$ Company war footing :-

4. Officers, 10 non-commissioned officers, 17 corporals, 22

A regiment is composed of 4 battalions of 4 companic 2 depôt companies, the latter having the same cadres as a c a peace footing, but 170 men instead of 66 . The regis battalion staff consist of :-

7 Field Officers, 5 Officers, and 4 non-commissioned o judants).

Regiment on a war footing is (not counting non-combata 7 lïeld Officers, 69 Officers, 148 non-commissioned c corporals, and 3,584 men; and a depôt of 12 Officers, 1 missioned officers, 16 corporals, and 340 men.

\section{Austria.}

Company peace footing :-

3 Officers, 1 cadet, 5 non-commissioned officers; 10 co lance-corporals, and 70 men.

Company war footing:-

4 Officers, 1 cadet, 5 non-commissioned officers, 30 co: lance-corporals, and $180 \mathrm{men}$.

An Austrian battalion has 4 companies; and an infant] in war time is composed of a field ragiment, a reserve $r \epsilon$ 5 ficld battalions) and one ergänzung battalion (which has The regimental staff is composed of 8 Field Officers, 80 11 non-commissioned officers.

Regiment on a war footing is (not counting non-combate 8 Ficld Officers, 108 Officers, 20 cadets, 125 non-commissio 750 corporals and lance-corporals, and 4,500 men.

Russia.

Company peace footing:-

3 Offcers; 1 jounker, 9 non-commissioned officers, IC 80 men, and 4 reserre men without arms.

Company war footing :-

4 Officers, 1 younker, 17 non-commissioned officers, 20 co men, and 12 reserve men without arms.

Battalion staff, 1 Field Officer and 1 Officer.

Regimental staff, 5 Field Officers and 1 Officer.

$A$ regiment consists of either 3 or 4 battalions, and car is composed of 4 field companies and 1 rille company.

Regiment of 3 battalions on a war footing is (not cor combatants) :- 
8 Field Officers, 64 Officers, 15 younkers, 255 non-c officers, 300 corporals, 2,220 men, and 180 reservo men $w$

Company peace footing:-

$$
\text { Italy. }
$$

4 Officers, 7 non-commissioned officers ( 2 of these corp 13 corporals and lance-corporals, and 73 men.

Company peace footing:-

5 Officers, 13 non-commissioned officers (4 of these corp 33 corporals and lance-corporals, and 145 men.

A regiment consists of 3 battalions of 4 companies ea mental and battalion staff consist of :-

5 Field Officers, 4 Officers, 10 non-commissioned officer are corporal-majors) and 1 corporal.

Regiment on a war strength is (not counting non-comk

5 Field Officers, 64 Officers, 166 non-commissioned corporals and lance-corporals, and 1,740 men.

ESTMIATES FOR THE ITALIAN NATY FOR ACCOUNT OF THE NEIV IRONCLAD "ITALI. ING AT CASTELLAMARE.

(Translated from the "Rérue Maritime et Coloni

Tre provincial budget for the sear 1878 has been alres to Parliament by the Government of Italy. The preli ment puts forward figures not very different from $t$ year. As to the Navy, the proposals aro presented in manner :-

Lire.

The total estimate, as voted in the past yenr $41,630,778$

Increase for $1878 \ldots \ldots \ldots \ldots \ldots \ldots \ldots \ldots 2,315,329$

$$
\text { Total } \overline{43,946,107} \text {. }
$$

On one side the reconstruction of the materiel of the other a larger number of ships commissioned and an in the position of the petty officers, hare made an inc estimates appear necessary.

The Naples newspaper, 'Il Piccolo Giomale Della Sera, 5 th, contains some information regarding the new "Italia," on the stocks at Castellamare, which has app sufficient interest to be brought to the knowledge of our

This ironclad, the largest of all the ships of war in $t$ the following dimensions approximately :- 